\title{
KAJIAN SOSIOLOGIS TENTANG PENGARUH SISTEM SOSIAL BUDAYA DALAM KEHIDUPAN BERMASYARAKAT
}

\author{
Nahriyah Fata \\ Lecturer of Tarbiyah and Teacher Training Faculty at IAIN Padangsidimpuan. \\ Jl. T. Rijal Nurdin Km.4,5 Sihitang Padangsidimpuan 22733 \\ Email: nahriyahharahap@yahoo.com
}

\begin{abstract}
Focus of study in this simple inscription about various sosial environment which can effect the grouth of motivation and success of studies in children and adolescents, both of them can get effect easily from Sosial environment where they are growth. Basically, there are effects which support and hamper and both of them will be discussed by explaining the role that is expected of environment which are revealed in the behaviour patterns of individual. As for the environment are the focus of this paper are family, Friend, School which will be explained by sociological approach especially the concept about the role children's interaction and adolecents with their environments. Sometimes because of parents' bussiness or lack of knowledge and limitation time for gathering with children and adolescents' it caused the role of this environment tends to ignored. So, through this simple inscription is expected focus introduction that environment gives direction for educators/ teachers and minimalized the negative effect or something which can humper motivating their successful in studying .
\end{abstract}

Keywords: Environment, Sociology.

\begin{abstract}
Abstrak
Fokus kajian dalam tulisan sederhana ini tentang berbagai lingkungan sosial yang dapat mempengaruhi pertumbuhan motivasi dan keberhasilan studi pada anakanak dan remaja, keduanya bisa mendapatkan efek dengan mudah dari lingkungan Sosial di mana mereka tumbuh. Pada dasarnya, ada efek yang mendukung dan menghambat dan keduanya akan dibahas dengan menjelaskan peran yang diharapkan dari lingkungan yang terungkap dalam pola perilaku individu. Adapun lingkungan adalah fokus dari makalah ini keluarga, teman, sekolah yang akan dijelaskan dengan pendekatan sosiologis terutama konsep tentang interaksi dan remaja anak-anak peran dengan lingkungan mereka. Kadang-kadang karena 'bisnis atau kurangnya pengetahuan dan keterbatasan waktu untuk berkumpul dengan anak-anak dan remaja orang tua itu disebabkan peran lingkungan ini cenderung diabaikan. Jadi, melalui tulisan sederhana ini diharapkan pengenalan fokus bahwa lingkungan memberikan arah bagi pendidik / guru dan meminimalkan efek negatif atau sesuatu yang dapat humper memotivasi sukses mereka dalam belajar.
\end{abstract}

Kata Kunci: Lingkungan, Sosiologi

\section{PENDAHULUAN}

Perspektif Sosiologi yang dimaksud dalam tulisan ini menyoroti pada aspek hubungan antar manusia secara individu, hubungan antar kelompok serta hubungan 
individu dengan kelompok dalam konsep bahwa manusia adalah sebagai makhluk yang bermasyarakat.Pola hubungan-hubungan tersebut lazim disebut sebagai interaksi sosial dimana anak dan remaja merupakan salah satu pihak di samping adanya pihak-pihak lain. Masing-masing pihak saling mempengaruhi, sehingga terbentuklah kepribadiankepribadian tertentu sebagai akibatnya.

Proses saling mempengaruhi itu melibatkan usur-unsur yang baik dan benar serta dapat juga unsur lain yang dianggap salah dan buruk. Unsur mana yang paling berpengaruh, biasanya tergantung dari mentalitas pihak yang menerima. Artinya sejauh manakah pihak penerima mampu menyaring unsur-unsur luar yang diterimanya melalui proses pengaruh mempengaruhi.

Proses pengaruh mempengaruhi tersebut dalam ilmu sosial disebut interaksi. Interaksi yang melibatkan anak dan remaja dalam kajian Sosiologi disebut proses sosialisasi. Sosialisasi merupakan suatu kegiatan yang bertujuan agar pihak yang dididik (anak dan remaja) mematuhi kaidah-kaidah serta nilai-nilai yang berlaku dan dianut oleh masyarakatnya. Tujuan pokok adanya sosialisasi itu bukanlah semata-mata agar kaidah itu dapat dimengerti tetapi lebih dari itu agar manusia bersikap dan bertindak sesuai dengan kaidah-kaidah dan nilai-nilai yang berlaku dan yang bersangkutan menghargai kaidah tersebut.

Dalam proses sosialisasi khususnya yang tertuju pada anak dan remaja terdapat berbagai pihak yang mungkin berperan. Pihak-pihak tersebut dapat disebut sebagai lingkungan sosial tertentu dan pribadi-pribadi tertentu. Perspektif Sosiologi lebih memusatkan pada lingkungan ini tanpa mengabaikan peranan individu- individu yang tidak mustahil juga memiliki pengaruh yang besar.

Fokus kajian dalam tulisan sederhana ini berkisar pada aspek berbagai lingkungan sosial yang dapat mempengaruhi tumbuhnya motivasi dan keberhasilan studi pada anak dan remaja, yang keduanya ini merupakan individu yang mudah mendapat pengaruh dari lingkungan sosial tempat dimana mereka dibesarkan. Pada hakikatnya ada pengaruh yang menunjang dan ada yang menghambat dan keduanya akan dibahas dengan mengungkap peranan yang diharapkan dari lingkungan-lingkungan tersebut yang terungkap dalam pola tingkah laku individu. Adapun lingkungan yang menjadi fokus kajian dalam tulisan ini adalah: a. Lingkungan keluarga, b. Kelompok sepermainan, c.Lingkungan sekolah. Lingkungan lain dapat juga mempengaruhi seperti lingkungan pekerjaan, tetangga, organisasi, masyarakat, negara dan lainnya, namun fokus kajian pada tulisan ini ada 3 aspek lingkungan di atas dengan kajian dari berbagai konsep- konsep Sosiologi.

\section{LINGKUNGAN KELUARGA}

Keluarga ada unit terkecil dari masyarakat, yang terdiri dari orangtua (ayah dan ibu), sanak saudara dan kerabat terdekat. Dalam keadaan normal lingkungan pertama yang berhubungan dengan anak adalah keluarga yaitu orangtua, saudara-saudaranya atau 
kerabat dekatnya yang tinggal serumah. Melalui lingkungan itulah anak mengenal dunia sekitarnya dan pola pergaulan hidup yang berlaku sehari-hari. Melalui lingkungan keluargalah anak mengalami proses sosialisasi awal. Orangtua, saudara maupun kerabat terdekat lazimnya mencurahkan perhatian untuk mendidik anak-anaknya agar memperoleh pola prilaku dan pergaulan yang baik dan benar, melalui penanaman disiplin, kebebasan atau penyerasian keduanya. Dalam keluarga; orangtua, saudara kerabat secara sadar atau tidak, melakukan sosialisasi yang biasa diterapkan dalam bentuk kasih sayang. Atas dasar kasih sayang itu anak dididik untuk mengenal nilai-nilai tertentu, seperti nilai ketertiban dan ketentraman, nilai kebendaan dan keakhlakan. Misalnya antara nilai kedisiplinan dan kebebasan senantiasa harus diserasikan. Pada suatu waktu anak boleh bebas bermain tetapi berhenti bermain jika waktu makan telah tiba. Antara kebendaan dengan keakhlakan misalnya; orangtua membelikan mainan yang diinginkan anaknya akan tetapi mainan itu harus dipelihara agar tidak cepat rusak. Apabila mainan itu rusak, maka orangtua harus dapat menahan diri untuk segera membelikan mainan yang baru. Melalui cara-cara seperti inilah nilai-nilai itu ditanamkan dan disosialisasikan.

Apabila usia anak meningkat ke usia remaja, penanaman nilai tersebut harus tetap dipertahankan yang tentunya dengan cara-cara yang sesuai dengan pertumbuhan jiwa remaja tersebut. Menurut Ilmu Jiwa usia remaja dianggap umur yang dianggap rawan karena pada saat ini remaja sedang mencari identitasdiri. Pada usia ini diperlukan tokohtokoh ideal yang pola prilakunya terpuji. Pertama remaja akan berpaling pada lingkungan terdekatnya yaitu orangtua, saudara atau kerabat dekatnya. Apabila tidak terpenuhi idealismenya dari lingkungan terdekatnya maka ia akan berpaling pada lingkungan lain yang belum tentu benar dan baik. Oleh karena itu keluarga sebagai lingkungan terdekat harus senantiasa siap untuk membantu remaja. Remaja lebih banyak memerlukan pengertian dari pada sekedar pengetahuan saja. Mereka harus mengerti mengapa manusia tidak boleh terlalu bebas dan tidak pula terlalu terikat. Orangtua terkadang lebih mementingkan keterikatan (disiplin) daripada kebebasan, sedangkan remaja lebih menyukai kebebasan. Namun manusia memerlukan keduanya dalam keadaan yang serasi dan seimbang, manusia yang terlalu disiplin akan menjadi robot yang tidak memiliki daya kreativitas, sedangkan manusia yang terlalu bebas akan menjadi makhluk lain yang bukan manusia.

Motivasi dan keberhasilan studi anak dan remaja didukung oleh keserasiankeserasian itu. Kalau pada usia anak-anak orangtualah yang harus menanamkan agar si anak berpengetahuan, sedangkan pada usia remaja orangtua harus memberikan pengertian dengan cara-carayang lebih dewasa. Anak dan remaja yang diharuskan belajar terus menerus atau dibebani dengan kewajiban mengikuti pelajaran dan ketrampilan tertentu akan mengakibatkan kebosanan, sehingga pekerjaan tersebut dianggap sebagai kegiatan rutin dan menjemukan. Anak dan remaja yang dibesarkan dengan cara seperti ini hanya 
dilatih untuk semata-mata berfikir tanpa mendidiknya untuk senantiasa menyerasikan pikiran dengan perasaan. Sebaliknya membiarkan anak atau remaja bersikap bebas dan bertindak semaunya juga buruk dan tidak benar. Mereka memerlukan tuntunan orangtua, saudara, kerabat terdekat, jika anak dan remaja tidak memperoleh tuntunan itu, maka lingkungan yang berpola seperti itu tidak menghasilkan pengaruh yang menunjang tumbuhnya motivasi dan keberhasilan studi, karena dilepas begitu saja. Kritik para remaja terhadap lingkungan keluarga biasanya meliputi aspek sebagai berikut:

1. Orangtua yang terlalu konservatif atau terlalu liberal.

2. Orangtua hanya memberikan nasihat tanpa memberikan teladan yang mendukung nasihat tersebut.

3. Orangtua terlalu mementingkan pekerjaan di kantor atau organisasi.

4. Orangtua mengutamakan pemenuhan kebutuhan material saja.

5. Orangtua diskriminasi antara anak yang satu dengan yang lain.

6. Orangtua maunya menang sendiri tidak mau menyesuaikan diri dengan kebutuhan dasar remaja yang cenderung berbeda.

Kritik para remaja tersebut terkadang memberikan jurang yang amat dalam antara hati para orangtua dengan mereka. Sehingga perlu diciptakan suasana yang positif, yang dapat mendukung tumbuhnya motivasi dan keberhasilan studi mereka. Suasana keluarga yang positif bagi tumbuhnya motivasi dan keberhasilan studi adalah keadaan yang menyebabkan anak atau remaja merasa dirinya aman atau damai bila di tengah keluarga tersebut. Menurut Soerjono Soekanto suasana tersebut biasanya menjadi terhambat dan terganggu bila:

1. Tidak ada saling pengertian atau pemahaman mengenai dasar-dasar kehidupan bersama.

2. Terjadinya konflik mengenai otonomi, di satu pihak orangtua ingin agar anaknya dapat mandiri, namun dalam kenyataan terkadang mereka mengekangnya.

3. Terjadinya konflik nilai-nilai yang tidak diserasikan atau tidak seimbang, misalnya antara kedisiplinan dan kebebasan, dimana salah satu lebih menonjol.

4. Pengendalian dan pengawasan yang berlebihan dari orangtua.

5. Tidak adanya rasa kebersamaan dalam keluarga.

6. Terjadinya masalah dalam hubungan antara ayah dengan ibu sehingga membuat anakanak merasa terganggu.

7. Jumlah anak yang banyak yang tidak didukung oleh fasilitas yang memadai.

8. Campur tangan pihak luar.

9. Status sosial ekonomis di bawah standar minimal.

10. Pekerjaan orangtua yang tidak seimbang dari jumlah income yang diterima dimana income istri lebih tinggi mengakibatkan suami merasa minder dan menyalurkan dalam kegiatan negatif. 
11. Aspirasi orangtua yangkadang tidak sesuai dengan kenyataan.

12. Konsepsi mengenai peranan keluarga serta anggota keluarga yang jauh dari kenyataan.

13. Timbulnya nepotisme dalam keluarga.

14. Persaingan yang tajam antara anak-anak sehingga menimbulkan pertikaian.

Dari uraian di atas dapat dicermati antara keseluruhan item di atasbahwa jika anak dan remaja dimaksudkan akan diberikan pengaruh yang dapat menunjang dan mendorong motivasi dan keberhasilan studi mereka, maka tugas orangtua adalahmengurangi hambatan tersebut dan menggantikan dengan suasana yang menjadi sebaliknya dari suasana di atas yaitu suasana yang kondusif dengan meminimalisir kemungkinan terjadinya konflik atau hambatan-hambatan sebagaimana telah diuraikan di atas. Yang pasti seluruh anggota keluarga harus bekerja sama untuk saling menghargai, menjaga dan memelihara saling pengertian antar sesama.

Dan pada hakikatnya agar dapat diantisipasi kemungkinan buruk sebagaimana yang telah diuraikan di atas dalam hal ini keluarga harus dapat memfungsikan dirinya secara maksimal dan proporsional. Menurut Horton dan Hurt fungsi keluarga meliputi: fungsi pengaturan seksual, reproduksi, sosialisasi, afeksi, penentuan status, perlindungan, ekonomi. ${ }^{1}$

Selanjutnya Menurut Hendi Suhendi ada tiga fungsi pokok keluarga yang tidak dapat digantikan oleh lembaga yang lain adalah: fungsi afeksi, fungsi biologis dan fungsi sosialisasi anak. Sedangkan fungsi keluarga yang telah bergeser dan telah diambil alih oleh lembaga masyarakat lain adalah fungsi pendidikan, perlindungan, rekreatif, ekonomi dan penentuan status².

Adapun kaitan antara semua fungsi keluarga tersebut dalam menumbuhkan motivasi dan keberhasilan studi anak dan remaja sangat dipengaruhi oleh sempurna, maksimal dan proporsional atau tidaknya dilakukan oleh orangtua sebagai pemimpin dalam keluarga. Karena itu keluarga dalam hal ini orangtua harus dapat memerankan fungsi ini dengan sebaik-baiknya agar keluraga sebagai lingkungan pertama dalam membentuk karakteristik anak akan memberikan manfaat yang besar bagi anak-anak dan para remaja. Sehingga dapat diminimalisir suasana-suasana yang dapat mengambat motivasi dan keberhasilan studi mereka. William Stainback dan Susan Stainback menyebutkan bimbingan orangtuaakan mampu mempengaruhi keberhasilan anak-anak di sekolah sebanding dengan IQ, bahkan mungkin lebih. Hasil penelitian menunjukkan bahwa baik buruknya prestasi

${ }^{1}$ Horton dan Hurt, Sosiologi,terj. Aminuddin Ram dan Tita Sobari, (Jakarta: Erlangga, 1996), hlm. 274279.

${ }^{2}$ Hendi Suhendi dan Ramdani Wahyu, Pengantar Sosiologi Keluarga, (Bandung: Pustaka Setia, 2001), hlm $45-46$. 
belajar anak di sekolah erat sekali kaitannya dengan bimbingan orangtua terhadap anaknya di rumah. ${ }^{3}$

Di samping itu M.Bashori Muchsin dkk . menyebutkan bahwa hal penting yang dilakukan orangtua dan keluarga adalah dengan memberikan teladan dan kesabaran secara moral. Teladan yang baik adalah merupakan sarana pendidikan yang sangat penting. Kesabaran dan tidak cepat bosan terhadap usahadalam membimbing anak-anaknya. Kesabaran merupakan sebab terpenting dalam keberhasilan pendidikan anak. ${ }^{4}$ Sebaliknya Hal penting pula yang perlu dihindari menurut Adil Fathi adalah pertengkaran suami istri di hadapan anak yang akan dapat berpengaruh buruk terhadap perkembangan anak utamanya terhadap mental mereka. ${ }^{5}$ Sehingga jika ini terjadi dapat dipastikan berpengaruh terhadap rendahnya motivasi dan keberhasilan studi mereka.

Dari uraian di atas terlihat bahwa meski berbeda sudut pandang dalam melihat peran keluarga itu namun intinya adalah keluarga tidak dapat diabaikan perannya, khususnya dalam menumbuhkan motivasi dan keberhasilan studi anak. Sehingga jelaslah bahwa betapa peranan keluarga sebagai lembaga pertama yang dapat menumbuhkan motivasi dan keberhasilan studi anak dan remaja sangat vital keberadaannya.

\section{KELOMPOK SEPERMAINAN (PIER GROUP)}

Lingkungan selanjutnya setelah keluarga adalah kelompok sepermainan. Pada masa kanak-kanak peranan kelompok sepermainan ini belum begitu tampak pengaruhnya, walaupun pada masa ini anak sudah mendapat pengaruh berupa pergaulan dengan orang di luar dirinya, seperti tetangga, teman satu kelas, anak kerabat dan lain sebagainya. Menurut pandangan sosiologis dalam hal ini Tonnis menyebutkan bahwa pergaulan dibedakan dalam bentuk sebagai berikut:

1. Gemeinschaft yaitu hubungan yang dibentuk oleh kodrat seperti hubungan dengan orangtua, tokoh masyarakat, pejabat, tokoh agama,dll.

2. Gesselschaft yaitu hubungan yang dibentuk oleh ikatan organisasi seperti organisasi politik, gang, klique dll.

Dengan demikian seseorang dalam pergaulan sehari-hari dapat melakukan hubungan baik secara Gemeinschaft, maupun Gesselschaft.Demikian juga halnya dalam keluarga muslim. Dalam ajaran Islam manusia diperintahkan untuk menciptakan suasana yang sakinah mawaddah warahmah dalam keluarga. Kenyamanan anggota keluarga di dalam rumah mereka akan mengurangi pergaulan yang disebabkan oleh pengaruh-pengaruh negatif baik dari bentuk hubungan yang gemeinschaft atau gesselschaft tersebut. Haryanto menyebutkan

${ }^{3}$ Wiiliam Stainback dan Susan Stain Back, Bagaimana membantu Anak anda berhasil di sekolah, (Yogyakarta: Kanisius) , hlm.5.

${ }^{4}$ M.Bashori Muchsin, Pendidikan Islam Humanistik, (Bandung: Refika Aditama, 2010). hlm, 126.

${ }^{5}$ Adil Fathi,Menjadi Ayah Sikses, (Jakarta: Gema Insani Pers, 2003), hlm. 121. 
Apabila istri, suami dan anak-anak tidak merasa terntram di rumah mereka, mereka akan mencari rumah kedua berupa: gang, discotik, bioskop dan lain sebagainya. ${ }^{6}$

Apalagi pada usia kanak-kanak adalah usia yang rawan untuk diperhatikan. Menurut Ali Qoimi persahabatan dalam dunia anak-anak tidak memiliki fondasi yang kuat. Sebab dasar persahabatannya adalah mencari kesenangan dan menyelamatkan diri dari kesendirian dalam bermain ${ }^{7}$. Meskipun belum tampak pengaruh secara langsung, tetapi mereka merekam dalam otaknya apa yang dilakukan oleh orang dewasa di sekelilingnya. Pada usia kanak-kanak biasanya mereka belum memiliki pengetahuan tentang pengambilan peran teman sepermainan dalam pembentukan tingkah lakunya. Biasanya sahabat-sahabat tersebut cenderung memberikan pengaruh yang baik dan benar, walaupun terkadang ada yang memberikan pengaruh yang kurang baik. Sahabat yang baik akan mendorong motivasi dan keberhasilan studi, dimana dia antara mereka terjadi proses saling mengisi yang mungkin berbentuk persaingan yang sehat. Sahabat yang baik merupakan unsur penggerak belajar dan menyelesaikan tugas-tugas lainnya sebaik mungkin. Kelompok persahabatan yang memberikan hasil yang positif terhadap perkembangan terhadap tumbuhnya motivasi dan keberhasilan studi anak tidak terlepas dari pengaruh yang dibentuk oleh komunikasi yang intensif antara anggotanya. Karena dalam proses pembelajaranintensitas komunikasi dan prilaku sangat dominan pengaruhnya. Fachrudin dalam Hasan Asarimenyebutkan bahwa pada usia kanak-kanak, anak berada pada fase mangadopsi, karena itu contoh prilaku yang baik dari orangtua, dan significant person lainnya sangat bernilai strategis. Dalam hal ini menurutnya perlu dibangun komunikasi yang religius. Untuk dapat membangun dan mengembangkan komunikasin religius itu antara orangtua, guru dan lingkungan sepermainan serta lingkungan pendidikan lainnya harus dilakukan secara sinergis. ${ }^{8}$

Akan halnya kelompok persahabatan seperti yang telah diuraikan di atas, kelompok sahabat ini akan berkembang menjadi lebih luas lagi dengan menyatunya anak dengan kelompok-kelompok lainnya. Persahabatan pada masa remaja mulai memiliki arti. Apalagi didukung dengan pertumbuhan anak menjadi remaja akan memiliki perkembangan pergaulan sesuai dengan perkembangan usianya, sehingga lingkungan permainan mereka tidak lagi meliputi satu kelompok saja. Kelompok tersebut bisa diperoleh di sekolah, tempat les, teman sepengajian atau tempat lainnya. Pergaulan itu pun tidak secara tatap muka langsung saja, dapat juga dilakukan melalui internet, hand phone, facebook dan lainnya. Kelompok permainan yang lebih besar dalam Sosiologi lazim disebut Klique.Klique ini secara ideal mempunyai peranan yang positif dalam membangkitkan motivasi dan keberhasilan studi. Peranan positif tersebut antara lain:

${ }^{6}$ Haryanto, Rasulullah Way Of Managing People, (Jakarta: Khalifa), hlm: 69.

${ }^{7}$ Ali Qoimi , Keluarga dan Anak Bermasalah, (Bogor: Cahaya,2002), hlm.12

${ }^{8}$ HasanAsari dkk, Pendidikan Psikologi Islami, Editor: AlRasyidin, (Bandung: Citapusta Media, 2007), hlm,186. 
1. Rasa aman dan rasa dianggap penting berasal dari keanggotaan suatu klique tertentu, hal mana penting bagi perkembangan jiwa yang sehat.

2. Dalam klique tersebut seorang remaja dapat menyalurkan rasa kecewanya, rasa takut, rasa khawatir, rasa gembira dan lain sebagainya dengan mendapatkan tanggapan yang wajar dari rekan-rekan se-klique.

3. Klique memungkinkan remajamengembangkan kemampuan dalam ketrampilanketrampilan sosial, sehingga dia lebih mudah menyesuaikan diri dengan keadaan.

4. Lazimnya suatu klique mempunyai pola prilaku dan kaidah-kaidah tertentu yang mendorong remaja untuk bersikap tindak secara dewasa.

5. Rasaaman yang ditimbulkan karena remaja diterima oleh kliquenya akan menimbulkan dorongan untuk hidup secara mandiri (artinya tidak tergantung pada siapapun).

Akan tetapi di balik peranan yang positif tersebut, harus dipertimbangkan pula bahwa kemungkinan timbulnya peranan yang negatif tetap akan ada. Kemungkinan terjadinya peranan-peranan yang negatif itu senantiasa harus dicegah baik oleh orangtua, para guru dan pihak-pihak lain yang merasa bertanggungjawab terhadap masa depan yang benar dan baik dari para remaja. Hal-hal yang negatif itu, antara lain sebagai berikut:

1. Klique dapat mendorong anggotanya untuk bersikap diskrimintaif terhadap bukan anggota klique (hal ini mungkin menimbulkan sikap tindak yang kurang adil).

2. Klique mendorong terjad;inya individualisme, oleh karena rasa kepatuhan hanya dikembangkan secara pribadi (individual).

3. Kadang-kadang timbul rasa iri hati dari anggota-anggota klik yang berasal dari keluarga yang kurang mampu, terhadap mereka yang berasal dari keluarga yang lebih mampu.

4. Kesetiaan terhadap klik kadang-kadang mengakibatkan terjadinya pertentangan dengan orangtua, saudara atau kerabat.

5. Klique merupakan suatu kelompok tertutup yang sulit sekali ditembus, sehingga penilaian terhadap sikap tindak anggotanya sukar dilakukan oleh pihak luar.

6. Suatu klik mendorong anggota-anggotanya untuk menyerasikan diri dengan pola kehidupan yang samna latar belakangnya, sehingga sulit untuk mengadakan penyesuaiandengan pihak-pihak yang berbeda latar belakangnya.

Kalau seorang remaja menjadi anggota klique tertentu, maka orangtua sebaiknya mempertimbangkan secara mantap terlebih dahulu, sebelum memberikan suatu keputusan. Jika klique tersebut memang cenderung kurang baik sehingga mungkin berkembang menjadi "gang", maka remaja harus diberi pengertian yang mendalam bahwa sebaiknya dia tidak menjadi anggota klqiue tersebut dan lebih baik mencari teman lain. Namun kalau ternyata bahwa klik tersebut lebih banyak menghasilkanhal-hal yang positif bagi motivasi dan keberhasilan studi, maka hendaknya remaja tersebut dibiarkan untuk menjadi anggota kliknya itu. Hal ini bukan berarti bahwa klik akan dapat menggantikan peranan orangtua terhadap anaknya yang remaja, kontak dan komunikasi dengan anak masih tetap harus 
dipelihara dan dikembangkan. Peranan orangtua terhadap anak (baik yang masih kanakkanak maupun yang sudah remaja) tidak dapat digantikan secara utuh oleh pihak-pihak lain. Oleh karena itu apabila salah seorang orangtua menikah lagi maka diperlukan suatu proses penyesuaian yang sangat mendalam.

Sebagai resep agar persahabatan dan kelompok sepermainan ini tidak sampai menimbulkan bahaya dan problem dalam proses persahabatan anak-anak Ali Qoimi menawarkan beberapa langkah berikut ini: ${ }^{9}$

1. Orangtua harus menumbuhkan keberanian dalam diri anak untuk mencari dan memilih teman tang terbaik di antaranya.

2. Membekali anak dengan pendidikan akhlak agar terhindar dari pengaruh pergaulan buruk.

3. Anak dididik untuk menggunakan kemampuan yang dimiliki untuk kebaikan bukan disalahgunakan.

4. Tidak memberikan anak bergaul dengan orang yang jauh lebih dewasa darinya.

5. Membiasakan anak untuk memperlihatkan akhlk mahmudah.

6. Mendidik anak tentang persahabatan yang diarahkan pada kemuliaan dan ketakwaan, sehingga kedua belah pihak dapat menjalankan haknya masing-masing.

7. Melatih kepribadian anak agar tubuh suburdan kuat.

8. Menjauhkan lingkungan rumah dari pengaruh buruk yang datang dari luar.

Orangtua hendaklah selalu mendorong anak dan remaja untuk menjalin hubungan persahabatan atau kelompok sepermainan bertdasarkan aturan-aturan yang benar, sehingga pencapaian tumbuhnya motivasi dan belajar mereka dapat diraih dengan maksimal.

\section{LINGKUNGAN SEKOLAH SEBAGAI KELOMPOK PENDIDIK}

Kelompok pendidik pada hakikatnya tidak hanya di sekolah saja, sebab sekolah adalah kelompok pendidik yang sifatnya formal. Namun dalam tulisan singkat ini dibatasi pada kelompok pendidik yaitu guru yang mengajar di sekolah yang diharapkan menciptakan suasana yang sangat mendorong motivasi dan keberhasilan studi anak didiknya di lembaga pendidikan formal. Hal ini dimungkin dengan ketetapan pemerintah tetap wajib belajar 9 tahun, sehingga dimungkinkan setiap anak akan mendapat pendidikan formal dari guru-gurunya. Adapun program yang diperankan guru di masing-masing jenjang pendidikan yang berbeda itu biasanya memiliki spesifikasi peran pula.

Pada sekolah-sekolah yang menyelenggarakan pendidikan awal seperti Taman Kanak-kanak, Sekolah Dasar, Sekolah Menengah Pertama, peranan guru sangat besar bahkan sangat dominan. Pada taraf pendidikan formal tersebut guru mempunyai peranan yang cenderung mutlak di dalam membentuk dan mengubah prilaku anak didik. Dengan demikian maka hasil kegiatan guru tersebut akan tampak nyata pada kadar motivasi dan

${ }^{9}$ Ali Qoimi, Keluarga dan Anak..., hlm.16. 
keberhasilan studipada taraf itu, yang mempunyai pengaruhyang sangat besar pada tahaptahap pendidikan selanjutnya.

Keadaan berubah setelah anak yang sudah menjadi remaja memasuki Sekolah Menengah Atas. Peranan guru di dalam membentuk dan mengubah prilaku anak didik, dibatasi dengan peranan anak didik itu sendiri dalam membentuk dan mengubah prilakuknya. Sudah tentu bahwa guru masih tetap berperan di dalam hal membimbing anak didiknya agar mempunyai motivasi yang besar untuk menyelesaikan studinya dengan baik dan benar. Setidaknya itulah yang menjadi peranan yang sangat diharapkan bagi guru yang mengajar di tingkat Menengah Atas.

Pada tahap ini para siswa yang terdiri dari usia remaja sudah mulai mempunyai sikap tertentu terhadap gurunya, kepribadiannya mulai terbentuk menuju kemandirian. Oleh karena itu para remaja mulai mengkritik keadaan sekolah yang kadang-kadang tidak memuaskan baginya. Biasanya kritik tersebut ditujukan pada aspek-aspek sebagai berikut:

1. Guru-guru yang usianya terlampau tua biasanya mengembangkan favoritisme terhadap murid-murid dan hanya melakukan tugas mengajar sebagai pekerjaan rutin yang tidak berkembang.

2. Kebanyakan guru tidak mau mencari penyesuaian diri terhadap nilai yang dianut oleh anak didik, sebaliknya cenderung membenarkan nilai-nilai yang dianut golongan tua.

3. Mata pelajaran yang diajarkan kebanyakan merupakan mata pelajaran wajib, sehingga tidak berpeluang mengembangkan bakat lainnya yang dianggap lebih diminati siswa.

4. Dalam proses belajar mengajar lebih banyak dipergunakan metode ceramah, sehingga menutup kemungkinan untuk berdiskusi dengan guru, akibatnya kurang interaksi positif antara siswa dan guru.

5. Kesempatan yang diberikan kepada siswa untuk mengelola sekolah sangat minim akibat siswa hanya mengejar target pertemuan tatap muka dan kehendak kurikulum yang kaku.

6. Hubungan antara guru dan siswa seperti hubungan atasan dengan bawahan sehingga hubungan tersebut bersifat formal.

Untuk dapat menghilangkan kritik terhadap gurudalam hal ini guru perlu introspeksi diri juga apakah prilaku yang ditampilkan sudah benar-benar membuat dirinya sebagai orang yang dapat "digugu'? Wiilaam Stainback menyebutkan bahwa dengan bertambahnya penekanan keterlibatan keluarga dan masyarakat dalam pendidikan dewasa ini, tanggung jawab seorang guru semakin luas dan tidak hanya di dalam kelas saja. Meningkatnya minat orangtua untuk terlibat ini mempunyai arti bahwa guru mendapat kesempatan mengembangkan kebersamaan dengan para orangtua dalam membantu perkembangan pendidikan anak-anak. ${ }^{10}$ Oleh karena itu kerjasama dalam bentuk pertemuan

${ }^{10}$ Stainback and Stainback, Bagaimana membantu Anak..., hlm. 7. 
orangtua dengan guru, kunjungan rumah (visite home) adalah sesuatu yang seharusnya biasa dilakukan oleh guru untuk mengetahui apa yang dilakukan oleh orangtua di rumah dalam membantu keberhasilan pendidikan anaknya.

Singkatnya sebagai lingkungan pendidikan yang dilakukan pada lembaga formal yaitu sekolah tugas guru amat penting dalam membangun interaksi yang edukatif. Dalam melaksanaklan interakti yang edukatif ini Abdullah Idi mengatakan pendidik perlu memahami karakteristik anak didik. Kegagalan menciptakan interaksi yang edukatif dan kondusif dapat disebabkan karena minimnya pemahaman guru tentang karakteristik anak. ${ }^{11}$

Sebagai usaha yang dapat dilakukan salah satunya adalah dengan melakukan secara maksimal kunjungan rumah dan pertemuan orangtua murid sebagaimana yang telah diuraikan di atas. Di samping itu dalam menghadapi tantangan globalisasi yang harus diantisipasi juga oleh pendidik atau guru adalah mengedepankan profesionalisme dalam bekerja. Ada beberapa hal yang harus diperhatikan . Sebagai mana yang dikemukakan oleh E.Mulyasa dalam Abdullah Idi bahwakesalahan yang sering dilakukan guru adalah: 1 . Mengambil jalan pintas dalam pembelajaran, 2.menunggu anak didik berprilaku negatif,3. Menggunakan destructive discipline, 4.mengabaikan perbedaan peserta didik, 5. Merasa dirinya paling pandai dan paling tahu, 6. Tidak adil dan diskriminatif, 7. Memaksa hak peserta didik. ${ }^{12}$

Kecenderungan globalisasi telah merubah tugas guru dari paradigma lama kepada paradigma baru. Guru diharapkan : tidak terjebak pada rutinitas belaka, mampu menyusun dan melaksanakan proses, strategi dan model pembelajaran PAIKEM, mengurangi dominasi guru sehingga memberikan kesempatan bagi anak didik untuk menmgembangkan diri menjadi lebih berani, aktif dan kreatif. Dengan demikian usaha untuk menumbuhkan motivasi dan keberhasilan studi anak dapat dicapai.

\section{PENUTUP}

Apa yang telah diuraikan di atas merupakan sebahagian kecil dari masalah-masalah yang dihadapi dalam pendidikan anak dan remaja, baik yang bersumber dari lingkungan keluarga (rumah), lingkungan sepermainan anak dan remaja ityu, maupun sekolahnya. Dalam menelaah masalah-masalah tersebut semestinya diadakan pemisahan yang tegasantara pengaruh positif dan pengaruh yang negatif bagi tumbuhnya motivasi dan keberhasilan studi, meskipun terkadang hal ini tidak sesuai dengan nilai-nilai yang dianut oleh orangtua.

Orangtua sebenarnya merupakan kunci untuk menumbuhkan motivasi dan keberhasilan studi anak dan remaja. Tidak akan adapihak lain yang dapat menggantikan peranan orangtua dengan seutuhnya. Keberhasilan orangtua di dalammendukung dan mendorong motivasi dan keberhasilan studi terletak pada eratnya hubungan antara

\footnotetext{
${ }^{11}$ Abdullah Idi, Sosiologi Pendidikan, (Jakarta: Rajawali Pers), hlm.122.

${ }^{12} \mathrm{Ibid}, 242$.
} 
orangtua dengan anak-anaknya. Orangtua merupakan tempat anak-anak berlindung dan mendapatkan kedamaian melalui keserasian antara kedisiplinan dengan kebebasan, ketentraman dengan ketertiban, nilai kebendaan dengan akhlak, yang tentunya mempertimbangkan pengaruh lain yang diperoleh anak dan remaja dari luar rumah.

Kesimpulannya, untuk dapat menumbuhkan motivasi dan keberhasilan studi anak dan remaja secara maksimal diperlukan hubungan yang sinergis antara lingkungan keluarga, sekolah dan kelompok sepermainan itu. Dapat dipastikan apabila salah satu lingkungan ini memberikan pengaruh yang timpang akan merembes pada pengaruh lingkungan pendidikan lainnya. Bagi anak yang sudah remaja maka diperlukan pula selektivitas dan filterisasi terhadap lingkungan sepermainan, yang pada akhirnya dapat menghindarkan diri dari pengaruh jelek pergaulan tersebut. 


\section{DAFTAR PUSTAKA}

Abdullah Idi, Sosiologi Pendidikan, Jakarta: Rajawali Pers, 2011.

Ali Qoimi , Keluarga dan Anak Bermasalah, Bogor: Cahaya, 2002.

Adil Fathi, Menjadi Ayah Sikses, Jakarta: Gema Insani Pers, 2003.

Hasan Asari dkk, Pendidikan Psikologi Islami, Editor: AlRasyidin, Bandung: Citapustaka Media, 2007.

Haryanto, Rasulullah Way Of Managing People, Jakarta Khalifa, 2011.

Hendi Suhendi dan Ramdani Wahyu, Pengantar Sosiologi Keluarga, Bandung: Pustaka Setia, 2001.

Horton dan Hurt, Sosiologi, terj. Aminuddin Ram dan Tita Sobari, Jakarta: Erlangga, 1996.

M. Bashori Muchsin, Pendidikan Islam Humanistik, Bandung: Refika Aditama, 2010.

Sorjono Soekanto,Sosiologi Suatu Pengantar, Jakarta: Rajawali Pers, 2003.

Wiiliam Stainback dan Susan Stain Back, Bagaimana membantu Anak anda berhasil di sekolah, Yogyakarta: Kanisius, 1999. 
FITRAH Vol.01 No. 1 Januari-Juni 2015

Dampak Perceraian Yang Tidak Sesuai Dengan

Prosedur Perundang-Undangan 